\title{
CONCERNING WITCHES: ERASTUS'S DEBATE WITH JOHANN WEYER
}

\begin{abstract}
Erastus himselfe, ... is forced to confesse, that these Greeke words ... are most commonlie put for illusion, false packing, cousenage, fraud, knaverie and deceipt: and is further driven to saie, that in ancient time, the learned were not so blockish, as not to see that the promises of magicians and inchanters were false, and nothing else but knaverie, cousenage, and old wives fables....
\end{abstract}

Reginald Scot on Erastus

\section{Background}

The debate between Weyer and Erastus on the punishment of witches came at a timely juncture in the history of witchcraft and witch-hunting. While the Western witchcraft paradigm had coalesced during the late Middle Ages, the great witch-hunts in which thousands of European men and women lost their lives were almost exclusively a civil legal phenomenon of the early modern era; indeed, the seventeenth century was the great century of witch-hunting. ${ }^{1}$ Whereas thirty years ago it would have been common to consider the entire learned witchcraft paradigm an elite construct which was largely imposed from above on an unwilling populace, recent scholarship has greatly expanded our knowledge of the rise of the learned witchcraft paradigm and the dialectical nature of witch hunting. One of the key insights of modern scholarship has been to

\footnotetext{
${ }^{1}$ What follows is a revised and expanded version of the article "The Debate between Johann Weyer and Thomas Erastus on the Punishment of Witches," in Cultures of Communication from Reformation to Enlightenment: Constructing Publics in the Early Modern German Lands, ed. James Van Horn Melton (Aldershot, Hampshire: Ashgate Press, 2002), 257-285. This chapter includes the full quotations of the primary sources omitted from the previous published version.

For a competent overview, see Brian P. Levack, The Witch-Hunt in Early Modern Europe, 3rd ed. (Harlow, England: Pearson Longmans, 2006).
} 
recognize the bottom up nature of many witchcraft accusations. ${ }^{2}$ Academic scholarship has also gotten beyond some of the rather crude early assertions that the witch-hunt was an unrestrained clerical "war on women," or represented an attempt by male medical practitioners to eliminate their midwife competitors, though the sex-related nature of the crime of witchcraft remains a central preoccupation for research. ${ }^{3}$ Finally, we know much more about the evolution of witchcraft beliefs in the late medieval period. The classic Western witchcraft paradigm only fully coalesced in the fifteenth century and represented an amalgam of accusations, many of which had previously been lodged against Cathars and Jews. ${ }^{4}$ Once this paradigm had been established, inquisitorial manuals such as Heinrich Kramer's infamous Malleus Maleficarum and court personnel disseminated this conception of the crime of witchcraft, the chief components of which were the belief that witches entered into an illicit pact with the devil in order to access his powers and that they used their malevolent powers to engage in concrete magical acts intended to harm their neighbors (maleficia). Subsidiary components of this paradigm, which varied in prominence from region to region, included the witch's mark, night flights, use of familiar spirits or other demonic agents, and obscene acts with the devil to seal the diabolical pact. The notion that witchcraft was a clandestine conspiracy in which the devil's minions regularly assembled at the witches' sabbath was a particularly vital component of the witchcraft paradigm in central Europe. ${ }^{5}$ By the seventeenth century, there was abundant anecdotal evidence that not only learned

${ }^{2}$ Robin Briggs, Witches and Neighbors: The Social and Cultural Context of European Witchcraft (New York: Viking, 1996).

${ }^{3}$ Among the more provocative studies are: Diane Purkiss, The Witch in History: Early Modern and Twentieth-Century Representations (London: Routledge, 1996); Lyndal Roper, Oedipus and the Devil: Witchcraft, Sexuality and Religion in Early Modern Europe (London: Routledge, 1994); and idem, Witch Craze: Terror and Fantasy in Baroque Germany (New Haven: Yale UP, 2004).

4 These trends are manifest in Alan Charles Kors and Edward Peters eds., Witchcraft in Europe 400-1700: A Documentary History, 2nd ed. (Philadelphia: University of Pennsylvania Press 2001). Regarding the particular role of the infamous Malleus Maleficarum in this process, see Hans Peter Broedel, The Malleus Maleficarum and the Construction of Witchcraft: Theology and Popular Belief (Manchester: Manchester UP, 2003). For a challenging synthesis of early modern demonology, see Stuart Clark, Thinking with Demons: The Idea of Witchcraft in Early Modern Europe (Oxford: Clarendon Press, 1997).

5 These topics are expertly handled in Richard M. Golden, ed. Encyclopedia of Witchcraft: The Western Tradition (Santa Barbara: ABC-CLIO, 2006). 
inquisitors and court personnel knew the narrative of the stereotypical acts performed by witches, but that even young children had imbibed this construct. ${ }^{6}$ On the eve of the Reformation, although witch-hunting itself was relatively infrequent, the intellectual apparatus that would make these bloodbaths possible had been fully articulated.

Both humanism and the Protestant Reformation offered new opportunities for intellectuals at least to question inherited medieval ideas of magic and witchcraft. This questioning was not limited to demonology, but at first chiefly concerned the perceived magical dimension of medieval Catholicism. Indeed, the criticisms of Erasmus were directed primarily against the superstitious ideas he saw within the church. ${ }^{7}$ Erasmus also engaged in a limited critique of late medieval demonology. He was able to show that the idea of witches making a pact with the devil was a "modern" innovation. Nevertheless, the humanist assault on witchcraft was incomplete and as William Monter has concluded, "Renaissance humanism did not attack the central presuppositions of the system of witchcraft constructed by the Inquisition."

Protestants were more adamant than humanists like Erasmus had been in their desire to root out the perceived unbiblical magic of medieval Catholicism. They rejected the many "false miracles" that had been associated with late medieval popular piety and even suggested that sanctioned clerical practices such as exorcisms were in actuality nothing more than black magic. ${ }^{9}$ In this atmosphere it was at least conceivable that Protestants would reject the entire witchcraft paradigm as extra-biblical scholastic speculation. Protestants were not so quick to disbelieve in the reality of diabolical magic (although they naturally condemned it), as they were to repudiate the magical dimension of medieval Catholicism. The writings of Martin Luther reveal an essential ambivalence regarding the question of witches. He certainly believed that witches were real, but he displayed a measure of uncertainty regarding their powers.

\footnotetext{
${ }^{6}$ See, for example, the adolescent who attempted to employ witchcraft accusations to her advantage in David Warren Sabean's "The Sacred Bond of Unity: Community through the Eyes of a Thirteen-year-old Witch (1683)" in Power in the Blood (Cambridge, Cambridge UP, 1984), 94-112.

7 Eire, War Against the Idols, see especially chapter 2, "Erasmus as a Critic of Late Medieval Piety," 28-53.

${ }^{8}$ E. William Monter, "Law, Medicine, and the Acceptance of Witchcraft, 1560-1580," in European Witchcraft, ed. E. William Monter (New York: Wiley, 1969), 57.

${ }^{9}$ Keith Thomas, Religion and the Decline of Magic (New York: Scribners, 1971).
} 
Jörg Haustein, in fact, traced the roots of Protestant skepticism toward witchcraft to the work of Luther. ${ }^{10}$ Nevertheless, Protestants did not decisively address the witchcraft question in the first half of the sixteenth century and, indeed, neither Luther, nor Zwingli, nor Calvin wrote what could be considered a major treatise on the subject. ${ }^{11}$ In fact, the first six decades of the sixteenth century witnessed a general lull in the production of demonological writings, both among Protestants and Catholics. ${ }^{12}$

The full potential of Protestant skepticism and Erasmian humanism did not make their mark on witchcraft theory until the work of Netherlandish physician Johann Weyer (1515-1588). Weyer garnered his knowledge of occult and magical arts at an early age through an apprenticeship to Heinrich Cornelius Agrippa von Nettesheim. After studying at the University of Paris, he was employed as the court physician to Duke Wilhelm III of Jülich-Cleves. ${ }^{13}$ His life's passion, however, was directed toward ending the cruel treatment of women accused of witchcraft. In 1563, he published the first edition of his masterwork, De praestigiis daemonum (On the Wiles of Demons). ${ }^{14}$ Weyer's De praestigiis daemonum made him the most influential Protestant demonological writer of the sixteenth century. The work ranged far beyond the specific topic of the punishment of witches and presented an encyclopedic treatment

10 "The continuity of Protestant thought, which leads ultimately to Weyer, does not begin with Brenz, but rather, is already present in Luther." Jörg Haustein, "Martin Luther als Gegner des Hexenwahns" in Vom Unfug des Hexen-Processes: Gegner der Hexenverfolgung von Johann Weyer bis Friedrich Spee [Wolfenbüttler Forschungen 55] ed. Hartmut Lehmann \& Otto Ulbricht (Wiesbaden: Harrassowitz, 1992), 51.

11 The idea that Calvinism had a special role in fomenting witch-hunting fervor was refuted by John L. Teal in "Witchcraft and Calvinism in Elizabethan England: Divine Power and Human Agency," Journal of the History of Ideas 23 (1962): 21-36.

12 See Monter, "Law, Medicine and the Acceptance of Witchcraft," 59-69.

13 Valente, Johann Wier; H.C. Erik Midelfort, "Johann Weyer and Transformation of the Insanity Defense," in The German People and the Reformation, ed. R. Po-Chia Hsia (Ithaca: Cornell, 1988), 234-261; idem, "Johann Weyer in medizinischer, theologischer und rechtsgeschichtlicher Hinsicht," in Vom Unfug des Hexen-Processes, 53-54; Carl Binz, Doctor Johann Weyer, ein rheinisher Arzt, der erste Bekaempfer des Hexenwahns: Ein Beitrag zur Geschichte der Aufklaerung und der Heilkunde, 2nd ed. (Berlin, 1896; reprint, New York: Arno, 1976).

${ }^{14}$ Johann Weyer, De praestigiis daemonum, et incantationibus ac veneficiis Libri $V$ (Basel, 1563). Six Latin editions of De praestigiis daemonum were published in Weyer's lifetime $(1563,1564,1566,1568,1577$, and 1583). Weyer expanded the work over time and included answers to his detractors' objections. His general pattern was to add new material, and he only infrequently rewrote sections. I will cite all of the editions as De praestigiis daemonum and distinguish between them by including the year of publication in each reference. For an excellent English translation of the 1583 edition and a bibliography of Weyer's works, see Mora, Witches, Devils and Doctors. 
of the devil, magic, and witchcraft. As such, the work served as a source book for other demonological writers. Weyer's motive was to undermine every conceivable foundation employed to apply the death penalty to witches. Weyer argued that the majority of those accused of witchcraft were deranged old women who suffered from an excess of melancholic humors. In this deranged state, they often dreamt up fantastic crimes that they confessed to inquisitors. ${ }^{15}$ Furthermore, Weyer argued that the alleged witches were not capable of producing the maleficia or harm of which they were accused. Weyer possessed a severely limited view of what witches could achieve, even with demonic assistance, and declared that the crimes they confessed were in fact impossible. The centerpiece of Weyer's work was his attack on the notion of the pact with the devil, which Weyer claimed was "deceptive, foolish and of no weight." ${ }^{16} \mathrm{He}$ also claimed that the biblical proof texts generally cited to condemn the accused to the flames did not apply to contemporary witches. Weyer thus offered an exhaustive rebuttal of the traditional rationales for imposing the death penalty on witches.

Erastus's literary foray into the world of demonology did not come as a result of a lifetime's fascination with witchcraft, but was a response to Weyer's plea for humane treatment of witches. Erastus sympathized with Weyer's compassion for the senile old women who suffered in the persecution, but he felt Weyer had gone beyond the boundaries of Scripture in arguing for sweeping clemency. These two Protestant physicians found themselves most unlikely adversaries in the dispute. ${ }^{17}$ They had much in common: they had mutual acquaintances, had both published with the famed humanist printer Johannes Oporinus in Basel, and were generally part of the same Rhenish-Protestant intellectual milieu. Beyond their confessional and occupational similarities, Weyer and Erastus also shared mutual disdain for Paracelsian medicine. I have previously argued that Weyer was a formative influence on Erastus's conception of Paracelsus. In the medical arena they were partisans, and Erastus cited Weyer to make his case against Paracelsus while Weyer was generous with his praise for Erastus's anti-Paracelsian work. ${ }^{18}$

${ }^{15}$ De praestigiis daemonum (1583), book 4, ch. 7. Mora, 183 .

16 De praestigiis daemonum (1583), book 3, ch. 3. Mora, 173 .

17 Regarding Weyer's religious confession, see Midelfort, "Johann Weyer and Transformation of the Insanity Defense," 238-239 and Jürgen Michael Schmidt, Glaube und Skepsis: die Kurpfalz und die abendländische Hexenverfolgung, 1446-1685 (Bielefeld: Verlag für Regionalgeschichte, 2000), 139-140.

${ }_{18}$ See chapter 8. For Weyer's positive assessment of Erastus's anti-Paracelsian work, see De praestigiis daemonum (1577), cols. 579 and 881. 


\section{Unmasking the Controversy}

Given their mutual friends and general agreement on most issues, it is not surprising that neither Erastus nor Weyer relished making an enemy of the other. The deference they showed to one another in the course of the debate has left a curious imprint on their dispute. Not only did they not demonize each other, a tactic that Jean Bodin would later employ in refuting Weyer, they refrained from even mentioning each other by name when refuting the opponent's position. ${ }^{19}$ This fact alone has undermined the historical understanding of their interaction. For instance, the otherwise vigilant editors of a modern English translation of De praestigiis daemonum were oblivious to the fact that one chapter was written in direct response to Erastus and incorrectly assume at one point that Weyer was addressing Bodin's criticisms, when he was actually countering Erastus. ${ }^{20}$ However, analysis of Erastus's correspondence and a close investigation of the text of De praestigiis daemonum reveal how much both Erastus and Weyer directly responded to the critiques of the other. At this point I will briefly outline the chronology of the Erastus/Weyer debate before turning to the actual content of the controversy.

Erastus was embroiled in the controversy regarding church discipline when he first turned his attention to the question of the punishment of witches. He wrote his first short treatise regarding witchcraft in late $1570 .^{21}$ This twenty-three page disputation refuting Weyer's appeal for

${ }^{19}$ Erastus does mention Weyer on at least two other occasions in his work. De medicina nova, 1:187; 4:131. Regarding Bodin's scandalous accusations, see Binz, Doctor Johann Weyer, 87.

20 The editors only briefly mention Erastus as an opponent of Weyer and are completely unaware of Weyer's direct refutation of Erastus's criticisms. The title of the chapter in question is "Adversus caput praecedens obiectionum quarundam productarum confutatio." De praestigiis daemonum, book 6, ch. 22 [sic] in the 1577 edition (cols. 741-763); book 6, ch. 24 in 1583 (cols. 742-762). Weyer made a new addition to this chapter in 1583 from cols. 742-744. (In Mora, Witches, Devils and Doctors, 543-544, from "The kindly reader ..." to "... let us return to our main argument.") The most egregious error of the editors of Witches, Devils and Doctors in the Renaissance is that they allow their assumption that Weyer is refuting Bodin to influence the text itself. On page 544 they add Bodin's name in brackets when Weyer clearly appears to be answering Erastus. Later they even venture to insert Bodin's name into the text (without brackets!), even though Weyer does not mention Bodin here in the 1583 edition. Weyer, De praestigiis daemonum (1583), col. 744. See figure 2 for definitive proof that Weyer was responding to Erastus in this passage.

${ }^{21}$ Erastus to Heinrich Bullinger, Oct. 29, [1570], StAZ, E II 345, fol. $741^{\mathrm{v}}$. "Mitto interim vobis quaestionem ad idem ferme argumentum pertinentem, an sagae nostrae iure divino capitaliter peccant, examinandam. Rogatus à viro opt. et doctiss. adde etiam 
clemency for witches was published as a chapter in the first volume of his anti-Paracelsian work De medicina nova Philippi Paracelsi in $1571 .{ }^{22}$ After the publication of the treatise, Erastus's opinions attracted Weyer's notice. Although no correspondence between the two survives, other letters from Erastus's hand that have been preserved bear witness to the fact that they exchanged letters. That it was an animated exchange can be drawn from a letter written by Erastus in the spring of 1572 to their mutual friend Theodor Zwinger, a Basel physician. Speaking of critiques of his De medicina nova, Erastus related:

But thus far I have received none that please me, ... with the exception of Weyer. He says that I do not think correctly concerning the punishment of witches and promises to refute me. God as my witness, if he does this, I will enjoy the greatest benefit. I have written him in as friendly a manner as possible, and have requested a debate, either privately or publicly. It makes little difference to me. If he would show me my error privately, I would not delay to admit it publicly. ${ }^{23}$

Although Erastus no doubt exaggerated his willingness to concede defeat, the desire to come to a mutual understanding and to avoid a public row was genuine. Nevertheless, Erastus was less than sanguine that such a rapprochement could be reached, as he revealed in a letter to the humanist physician Joachim Camerarius, II in early 1573:

piisimo [Johann Ewich?] scripsi, qui contra me sentit cum Wiero Medico in lib. De praestigiis daemonum." See also the contemporaneous letters to Johann Jakob Grynaeus (Basel UB, G II 4, fols. 287 and 282). These letters suggest that Erastus was using the 1568 edition of De praestigiis daemonum. That he had access to this edition is confirmed by the university's purchase of the volume in 1568. UAH A-16o/ 8, fol. 7 .

${ }^{22}$ This disputation is entitled "De lamiis seu strigibus non inutilia scitu" in the table of contents and is found in De medicina nova, 1:193-215.

${ }^{23}$ Erastus to Theodor Zwinger, Heidelberg, Easter [April 6, 1572], Basel, Öffentliche Bibliothek der Universität Basel, Fr. Gr. MS II 4, no. 93: "Sed huc usque nullum audivi, qui mihi gratificaretur (quod unicè tamen, cupio, pete, oro) excepto Wiero. Hic enim de Lamiarum pœnis me non recte sentire ait, probaturumque promittit. Deum testor, si fecerit summi beneficii loco habebo. Scripsi ei, ut amicius non possem, et ad defensionem seu privatam seu publicam cohortatus sum. Mea non refert utro malit modo. Si clam mihi errorem monstrabit, ego publicè fateri non cunctabor. Una enim veritas cum mihi proposita sit, ac me errare posse sciam, non dubitabo meliora docenti publicè agere gratias, et cuius opera p[ro]fecerim aliis indicare. Rog[o] igitur te, qui ingenio, iudicio, et doctrina vales plus aliis multis, ne confere nostra graveris ita, ut amicitiae nihil tribuas, publici boni solius rationem habeas. Reddam ego pro viribus beneficium, modo possim." Erastus repeated this claim regarding his willingness to concede defeat were Weyer willing to publicly correct him in the introduction of the Repetitio disputationis de lamiis, fol. ):( $3^{\mathrm{v}}$. See full citation below. See Appendix B, text no. 11 for more of this letter. 
I have received letters from Dr. Johann Weyer, and I have seen others which he had sent to other friends (for they sent two to me) in which he also wants to demonstrate most strongly and copiously his opinion concerning the punishment of witches ..., and meanwhile he endeavors to persuade all that we do not disagree. If this were actually the case, I would truly rejoice. But I fear that we will not be able to reach an understanding. ${ }^{24}$

Although this is a secondhand source, the notion that Weyer thought that Erastus was near his position and could perhaps be won over to his perspective is telling. As I shall relate below, their assumptions about the actual powers of witches and the devil were quite similar; their chief difference was their conclusion about the necessary penalty for witchcraft.

Who were these friends that supplied Erastus with letters from Weyer? Perhaps one was Zwinger, since Erastus had asked him for assistance with the anti-Paracelsian project. The Bremen physician Johann Ewich (15251588), who shared Weyer's opinion regarding the punishment of witches, may also have served as the intermediary. Erastus had been in contact with Ewich for some time, and his name often appears in Erastus's correspondence. Another plausible connection between Weyer and Erastus, however, came with the presence of three of Weyer's sons in the Palatinate in the 1570 s. Dietrich Weyer apparently entered Palatine service in the late 1560 s, and by the mid-1570s, he was a rising star among the Palatine civil servants, taking a position on the high council in $1574 .^{25}$ Volker Press regarded Dietrich as a fairly radical Calvinist partisan and characterized him as a "restless spirit, with a marked tendency toward adventure." ${ }^{26}$ In fact, Dietrich himself became a key player in the interventionist foreign policy so detested by Erastus and Ursinus. Another son, Johann Weyer II, enrolled in the University of Heidelberg in early 1573 and later also entered the service of the Palatine court. ${ }^{27}$ The connection between the elder Weyer and Erastus may have been made through yet a third son,

${ }^{24}$ This remark came in a letter in which Erastus reported having begun the fourth volume of De medicina nova. Erastus to J. Camerarius II, Jan. 31, [1573], UB Erlangen (Sammlung Treu), no. 6: "Accepi literas à D. Joh. Wiero, et alias ad amicos alios missas vidi (Miserunt enim mihi duo) in quibus et sententiam suam de strigum poena in quinta libri sui editione copiosius et firmius vult demonstrare: et interim persuadere conatur omnibus nos non dissentire. Quod si ita est, gaudeo equidem $\mathrm{pl}$ [urimu]m. At valde vereor ut sit monstraturus consensum."

${ }^{25}$ Schmidt, Glaube und Skepsis, 140-142; Press, Calvinismus und Territorialstaat, 257. Schmidt infers that Dietrich may have been in the Palatinate as early as 1567 .

${ }^{26}$ Press, Calvinismus und Territorialstaat, 257.

27 Toepke, Die Matrikel der Universitaet Heidelberg, 2:65. 
the physician Heinrich Weyer, who also spent some time in the Palatinate and was closely associated with Erastus's protégé Heinrich Smet. ${ }^{28}$

Given Dietrich Weyer's close association with the pro-disciplinary party and Erastus's rivals Caspar Olevianus and Wenzel Zuleger, we must engage the question of whether Erastus's personal animus against Dietrich's partisans conditioned his antipathy toward Johann Weyer's demonology. The fact that Dietrich Weyer was able to get the disciplinistdominated state to go along with his father's position on witchcraft suggests that in at least a small way the controversy between Erastus and Johann Weyer mirrored the split between Erastus and Dietrich Weyer's "Calvinist" faction. However, Erastus apparently composed his first disputation against Weyer's demonology prior to Dietrich's assumption of a major role in Palatine politics. Likewise, the basic Palatine governmental position in line with Johann Weyer's views had been determined since the mid-1560s and first defended by the later anti-disciplinist councilor Christoph Prob, who is generally seen as an ally of Erastus. ${ }^{29}$ Similarly, the university arts professor Hermann Witekind, who seems to have associated with the ethnic German anti-disciplinist faction rather than the largely foreign Calvinist faction during the disciplinary struggle, broke with Erastus and sided with Johann Weyer in the witchcraft debate. ${ }^{30}$ Even more ironically, Erastus's close associate Johann Jakob Grynaeus supported allowing the publication of Witekind's book in 1585, whereas Daniel Tossanus, the ardent Calvinist who had been involved in Erastus's excommunication, obstructed its publication. ${ }^{31}$ Thus, the church discipline controversy does not seem to have had a decisive impact on the witchcraft debate, beyond perhaps heightening Erastus's own need to associate himself with more conventional intellectual opinions. ${ }^{32}$

Perhaps feeling a little hemmed in with Johann Weyer's opinions in favor in the Palatinate and both Zwinger and Ewich solidly in Weyer's

${ }^{28}$ Schmidt, Glaube und Skepsis, 142. See Smet, Miscellanea ... medica. Smet passed a greeting from Heinrich Weyer to Erastus in a letter from March 29, 1571. Miscellanea ... medica, 244-246.

${ }^{29}$ Schimdt, Glaube und Skepsis, 137-143.

${ }^{30}$ Hermann Witekind [alias Augustin Lercheimer], Christlich Bedencken und Erinnerung von Zauberey, 3rd ed. (Speyer: Albin, 1597). See Schimdt, Glaube und Skepsis, 205-242.

${ }^{31}$ Schmidt, Glaube und Skepsis, 211-212. Thus Schmidt also argues that there was not a close association of the theologians and Palatine policy of non-persecution.

32 Adding to the irony, Clark also noted that "European states with Erastian Protestant churches" tended toward "comparably mild prosecution." Thinking with Demons, 517. 
camp, Erastus turned to his trusted patron Heinrich Bullinger for support. Also in January of 1573, Erastus wrote to Bullinger:

Weyer threatens a confutation of our opinion concerning the punishments of witches and has written to many that you agree with him, (I have seen manuscripts of his letters) and for his cause he has many living witnesses. I have replied in a different manner in which you would perhaps not disapprove (I hear [that he is] contaminated by the error of Schwenckfeld) that you would by no means allow that witches should not be punished. ${ }^{33}$

While it might seem that Erastus was being presumptuous to count on Bullinger's backing (he even refers to the matter as "our opinion"), in fact, Bullinger's position was close to Erastus's. Bullinger would also write a demonological tract that defended the proposition that witches merited capital punishment, although the work's primary animus was directed against vestiges of popular magic in the late medieval Catholicism. ${ }^{34}$ Erastus's letter is also intriguing for its insinuation that Weyer was "contaminated with the error of Schwenckfeld." Kaspar Schwenckfeld, the Silesian spiritualist reformer, had de-emphasized the importance of outward sacraments in favor of participating in a spiritual inner-communion with Christ. After his falling out with Luther over the Lord's Supper and his unwillingness to establish a firm relationship with the established Protestant church, he was increasingly viewed as a pariah by the magisterial Reformers, both Lutheran and Reformed. Erastus was thus relaying serious accusations to Bullinger, a man who knew the Schwenckfeld "heresy" well. It must be remembered, however, that this was a private disclosure to a close friend; in his publications, Erastus always referred to Weyer as a "most pious man." Erastus may have employed this slur to cover the charge of spiritualism in the mode of Erasmus or Sebastian Castellio in that he questioned whether heretics (in this case witches) should be punished. ${ }^{35}$ Perhaps the ambiguity of Weyer's confessional

${ }^{33}$ Erastus added this comment in the postscript of a letter dated Jan. 13, [1573]. Erastus to Bullinger, StAZ, E II 361, fol. 31: "Wierus minatur confutationem sententiae nostrae de Lamiarum pœnis: et te consentire secum scripsit ad diversos: (Vidi literas eius manuscriptas) eiusque rei plures se habere testes vivos. Ego respondi alia te fortasse non improbare (Audio Schvenckfeldii errore contaminatum) hoc de strigibus non puniendis te nequaquam admittere."

${ }^{34}$ Heinrich Bullinger, Wider die Schwartzen Künst/ Aberglaubigs segnen/ und unwarhafftigs Warsagen/ und andere dergleichen von Gott verbottne Künst: ein kurtzer Tractat auß heiliger Schrifft/ und warhafften guten gründen, in Abraham Sawr, ed. Theatrum de Veneficis (Frankfurt: Nicolaus Basseus, 1586), 298-306. See http://www.rainerhenrich.ch/schwarzkunst.html.

${ }^{35}$ On Erasmus's influence on Weyer, see Midelfort, "Insanity Defense," 238-240. 
stance led his contemporaries to ponder whether his equivocation on the punishment of witches betrayed religious sympathies beyond the pale of conventional Protestantism. This accusation of contamination with "error of Schwenckfeld" would prove ironic, since later Erastus himself would be accused of devotion to the spiritualist's writings. ${ }^{36}$

Despite the behind-the-scenes negotiations, Weyer apparently was not interested in Erastus's offer to stage a public debate. He included a barb that appears to refer to Erastus's invitation to debate in the 1577 edition of De praestigiis daemonum. He admitted that he "shrinks from debate and constant arguing," but added, "these things I leave freely for those who enjoy them." ${ }^{37}$ At any event, the proposed debate never took place, and after the epistolary posturing of 1572-1573, the controversy fell dormant for some years.

The advent of a new edition of De praestigiis daemonum in March of 1577 reopened the dispute. The new edition was buttressed by the inclusion of the Liber Apologeticus, which reprinted many letters to and from Weyer. ${ }^{38}$ At the same time as the printing of the expanded version of $D e$ praestigiis daemonum, Weyer also published an abridgement of his central arguments entitled De Lamiis Liber. ${ }^{39}$ Beyond these new publications, Weyer made an addition to the text of De praestigiis daemonum, which directly answered many of Erastus's criticisms. This chapter, "A refutation of the objections that have been raised against the preceding chapter," defended his proposition that those accused of witchcraft were deranged women and should be thus spared the death penalty. ${ }^{40}$ Weyer ended the chapter by placing his opponents on notice that, as far as he was concerned, the debate was over: "they can expect no further response from me. I say this lest they lay claim to victory on the basis of my silence."41

\footnotetext{
36 Rott, "Neue Quellen für eine Aktenrevision," 5-9; Burchill, The Heidelberg Antitrinitarians, 17; idem, "Die Universität zu Heidelberg," 245. Pigafetta alleged that Erastus preferred reading Schwenckfeld at home to hearing sermons in church. Given the animosity that developed between Erastus and the leaders of the Palatine church, it does not seem unlikely that he would have missed a few services.

${ }^{37}$ De praestigiis daemonum (1577), book 6, ch. 22 [sic], col. 762. Translation from Mora, Witches, Devils and Doctors, 557.

38 Including letters of Zwinger and Ewich. De praestigiis daemonum (1577), cols. 901906.

39 Johann Weyer, De Lamiis Liber (Basel, 1577).

40 De praestigiis daemonum, book 6, ch. 22 [sic] in the 1577 edition (cols. 741-763); book 6, ch. 24 in the 1583 edition (cols. 742-762). (N.B. The eighth and ninth chapters in terms of actual succession of the 1577 edition bear the numbers VI and VII.)

${ }^{41}$ Weyer, De praestigiis daemonum (1583), col. 763. Translation from Mora, Witches, Devils and Doctors, 557. This disclaimer first appeared in the 1577 edition.
} 
Within weeks of the publication of the 1577 edition of De praestigiis daemonum, Erastus was at work on a new rebuttal. ${ }^{42}$ Erastus indignantly complained that Weyer had not taken his criticisms to heart and simply put forth his old opinions without any alteration. Weyer's compendium of his thoughts on witchcraft, De Lamiis Liber, enraged Erastus the most, since he found in it "nothing at all that was of any significance" that he "had not already solidly refuted." 33 Convinced that Weyer's relative silence proved the veracity of his criticisms, Erastus was emboldened to augment his critique. He expanded his original twenty-three page disputatio "De lamiis seu strigibus non inutilia scitu" into the 127-page Repetitio disputationis de lamiis seu strigibus (Repetition of the Disputation on Witches).

The Repetitio disputationis de lamiis seu strigibus was published by Perna in Basel in 1578 in octavo format without illustrations. ${ }^{44}$ Erastus's brother-in-law Johann Jakob Grynaeus arranged the details of its publication. ${ }^{45}$ The stated purpose for the book was for the good of Christendom and ended with a prayer for consensus on this contentious issue. Erastus, however, also had a more earthly goal in mind by dedicating the book to members of the Basel city council. With the accession of the Lutheran Elector Ludwig VI, Erastus realized that his days in Heidel-

42 The book was published in March; Erastus was at work on the refutation by May. Erastus to Grynaeus, May 10, (15)77, Basel UB, G II 4, fol. 207: "Cœpi ... scribere confutationem libri, quem adversus me scripsit Joh. Wierus De Lamiis. Impressit istic successor in Officina Oporiniana. Eius exemplum, si potest seorsum haberi à libro de praestig. Daemonum quintum iam edito, mihi per hunc [Andream] Ruinellam mitti velim. ... Scripsit modeste Wierus, qua in re ne inferior eo sim, sed superior, operam dabo. Rem totam sic explicabo adiuvante Deo, ut porrò neminem aliquid temere desideraturum confidam. Fundamenta totius disputationis feliciter sunt iacta, ut superstructio non videatur operos[a] futura. Turpiter se dedit Wierus, nisi fallor, dum et Mosen et omnium aetatum intelligentes inscitiae et ruditatis accusare non veretur."

${ }^{43}$ Repetitio disputationis de lamiis seu strigibus: in qua plenè, solidè, \& perspicuè, de arte earum, potestate, itemque pœena disceptatur ... (Basel: Pietro Perna, [1578]), preface, fol. ):( $3^{\mathrm{v}}$. "Nihil enim prorsus, quod quidem momenti alicuius esset, deprehendi, quod non antea solide à me confutatum fuisset."

44 Though the work lacks a date on the title page, its dedicatory letter is dated April 1, 1578, and it appeared at the Lenten Frankfurt fair that year. (Die Messkatalog Georg Willers, 2:294.) Robert Muchembled credits what is perhaps the first known illustration of a witch riding a broom to the French edition of Erastus's treatise, but this attribution is manifestly a false citation. La Sorcière au village (XVe-XVIIIe siècle) ([Paris]: Archives Gallimard Julliard, 1979), illustration no. 13.

${ }^{45}$ Erastus to Grynaeus, Aug. 18, (15)77, Basel UB, G II 4, fols. 211-212: "Mitto praeterea libellum de Strigib. quem, cum videbis oportunum esse curabis excudi. De dedicatione scripsi tibi, quae mea sit sententia: et literas et nunc accepisse arbitror. Tu praefationis partem posteriorem mutabis pro ratione circumstantiarum." 
berg were numbered. Although Erastus entertained a number of career options (see below), relocating to Basel was his preference. The dedication of the Repetitio disputationis de lamiis seu strigibus must be seen both as an effort to influence the Basel magistrates on the question of the punishment of witches and as an attempt to further ingratiate himself with the Basel political elite. ${ }^{46}$

Although Erastus was a relative novice in the field of demonology, his treatises on witchcraft proved to be among his most widely read works. ${ }^{47}$ Prior to publication of Jean Bodin's refutation of Weyer, Erastus's Repetitio and the original disputation from De medicina nova were translated into French and published as a complementary addendum to Weyer's work in 1579, which was itself reprinted in $1885 .{ }^{48}$ The Repetitio was reprinted with the 1581 edition of Nicolaus Jacquier's Flagellum haereticorum fascinariorum and again by itself in Amberg in $1606 .{ }^{49}$ It was thus a modest publishing success, although the fact that it was never translated into German limited its popular impact. Its popularity does not compare with that of Weyer's De praaestigiis daemonum or Bodin's later refutation, De la demonomanie des sorciers. ${ }^{50}$

Ironically, Erastus's brief disputation "De lamiis seu strigibus non inutilia scitu," buried in the pages of his De medicina nova, elicited a longer response from Weyer than his lengthier Repetitio of 1578 . I have only been able to uncover one new reference in the 1583 edition of De praestigiis daemonum that responds to Erastus's work of $1578 .{ }^{51}$ In this section Weyer responded to some of the specific passages from Dioscorides and

46 The ambitions to use this book to garner favor in Basel are obliquely discussed in a letter from Erastus to Grynaeus, Aug. 5, (15)77, Basel UB, G II 4, fols. 203-204.

${ }^{47}$ It likely rates behind his Explicatio gravissimae questionis utrum excommunicatione in terms of readership and his anti-Paracelsian disputations in terms of significance. It was not reprinted as frequently as his treatise on the Lord's Supper, the Gründtlicher bericht.

48 "Deux Dialogues de Thomas Erastus, Docteur en Medecine à Heidelberg, touchant le pouvoir des Sorcieres: \& de la punition qu'elles meritent," in Iean Wier [Johann Weyer], Histoires, disputes et discours, des illusions et impostures des diables, des magiciens infames, sorcieres \& empoisonneurs, pp. 757-875 (with its own unpaginated index following the Weyer index) ([Geneva]: Pour Iaques Chouet, 1579 (NLM 4737); reprinted, Paris: Lecrosnier and Delahaye, 1885; reprinted, New York: Arno, 1976).

49 "Disputatio de Lamiis, seu Strigibus, in qua de earum viribus perspicuè disputatur à Thoma Erasto," reprinted in Nicolas Jacquier's Flagellum haereticorum fascinariorum, ed. Heinrich Myntzenberg (Frankfurt, 1581); Disputatio de lamiis seu strigibus ... (Amberg: Michael Forster, 1606).

${ }^{50}$ Jean Bodin, De la demonomanie des sorciers (Paris, 1580).

51 This being the insertion from col. 742 , line 41 to col. 744 line 33. De praestigiis daemonum (1583). See note 20 above and figure 2 below. 
Galen that Erastus had assembled against his understanding of the meanings of words from the pa@uaxov (pharmakon) family. ${ }^{52}$ Aside from this brief treatment of etymological issues, Weyer had basically kept his promise of 1577 that he would not respond to further critiques to his work. Erastus's death in 1583 prevented his response to Weyer's final Latin edition of De praestigiis daemonum, although by this time Bodin had already championed Erastus's side of the debate, albeit with much less decorum.

\section{Erastus's Conception of Magic and Witchcraft}

A simple definition of magic undergirded Erastus's demonology: magic was the attempt to produce an effect that would have been impossible to achieve using natural powers. In Erastus's scheme, all individuals who sought to produce an outcome exceeding the powers of nature could fairly be called magicians. Almost from the beginning of time individuals had existed who claimed to know more, or to be able to accomplish things, beyond what could be possible through natural means. Erastus believed that any such attempt to produce supernatural effects must necessarily call upon a higher force, since humans could not exceed the powers of nature. In general, magicians employed conjurations, incantations, and other such rites in their attempt to produce magical effects. However, since these physical or verbal acts had no power in themselves, magicians were forced to resort to demonic assistance to accomplish results. ${ }^{53}$ Erastus also rejected magical practices on the grounds that the Bible prohibited them. The Pentateuch proscribed all such auguries, enchantments, and divinations. Thus, magical arts suffered a double condemnation in Erastus's mind: they were necessarily demonic and God explicitly forbade them. A person could either seek to improve his condition by natural means, while relying on benevolent providence, or turn to the help of demons. There was no middle ground for white magic. ${ }^{54}$

Although Erastus employed an inclusive definition of magic, he used magus, the Latin word for magician, in two distinct senses in his work. In keeping with his broad definition of magic, he often employed it as

\footnotetext{
${ }^{52}$ Erastus maintained that the words possessed the connotation of enchanting while Weyer argued that they suggested the use of poison. See below.

${ }^{53}$ Repetitio disputationis de lamiis, 13-14.

${ }^{54}$ Ibid., 46-47.
} 
a general term denoting all who would seek to exceed natural powers, including learned magicians, enchanters, soothsayers, witches, and so forth. On other occasions he used magus to specifically denote a learned magician. In line with the first usage, Erastus conceptualized witches as simply one type of magician. Since Weyer had attempted to drive a wedge between culpable, learned magicians and ignorant, harmless witches, Erastus stressed the point that witches must also be numbered among magicians. His basic argument for including witches in this category remained a simple one: all who sought to exceed the powers of nature were, by definition, magicians. ${ }^{55}$

Since one of Weyer's chief arguments for clemency for accused witches was based on the meaning of Old Testament words for sorcerers, Erastus was very careful to explain the various names of witches. Revealing his own area of expertise as a humanist physician, Erastus spent most of his time on the basic Greek and Latin words for witches. He first addressed terms of the pa@uaxov (pharmakon) family. ${ }^{56}$ This word's basic meaning is that of a drug or poison and is the root of the English word "pharmacy." Most of the words in this family have the second sense of connoting sorcery or enchantment. Erastus explained the etymological link between the differing concepts by noting that because in ancient times many druggists made magical potions or said incantations over their medications, the word came to apply to making spells or incantations. Erastus recognized that the words in the pharmakon family have a range of meaning. He did not try to argue that it could not mean poison or poisoner; rather, he sought to demonstrate that the word also could denote sorcery and incantation in writers such as Plato and Aristotle. ${ }^{57}$ More importantly for Erastus, the New Testament use of a word of this family, pharmakeia, clearly signified magical arts or sorcery, and not poison. ${ }^{58}$ Thus, Erastus was able to assert that there was a long heritage for using words of the pharmakon family to describe sorcerers or enchantresses.

After treating the most common Greek terms for witches, Erastus discussed the various Latin names. He refused to turn this into a treatise on narrowly defined types of sorcery, but used the exercise to

55 Ibid., 15, 46. See Clark, Thinking with Demons, 201-202.

$56 \Phi \alpha \varrho \mu \alpha \varkappa \varepsilon \iota \alpha, \varphi \alpha \varrho \mu \alpha \varkappa \varepsilon v \tau \varrho \iota \alpha, \varphi \alpha \varrho \mu \alpha \varkappa \iota \sigma$, etc., are some of the forms used by Erastus. When speaking of persons rather than sorcery, in general he used the feminine gender.

${ }^{57}$ Repetitio disputationis de lamiis, 6-10.

${ }^{58}$ Ibid., 11. See especially Rev. 18:23, which speaks of the "sorcery" ( $\left.\varphi \propto \varrho \mu \alpha \varkappa \varepsilon \iota\right)$ of Babylon. Bauer, A Greek-English Lexicon, 854. 
illustrate the full range of witches' vices while maintaining the underlying commonality of all types of magic. He first answered why witches were called lamiae. In antiquity, lamiae were thought to be specters or apparitions who appeared in the night in the form of beautiful women. After having intercourse with young men, they would devour their lovers. He was not hesitant to admit that modern witches were not lamiae themselves but were merely called that because they claimed to do similar acts. Likewise, modern witches were frequently called striges after legendary birds that drank children's blood at night. The name applied since it was popularly thought that witches desired the blood of infants. Another popular name for witches was venefica, which, Erastus explained, was similar to the Greek pharmakeutria. Like pharmakeutria, the root of venefica meant poison or venom, and this name could easily be applied to witches since they often made poisons as well as love potions. The Latin malefica, (literally, evil doer) picked up another essential characteristic of witches: the almost universal intent to harm others with their magic. Even more to the point was the name incantatrix, or enchantress, which stressed their proclivity to use spells and magical songs. Erastus emphasized this category, since its wide range of examples in classical literature helped prove the antiquity of witchcraft. The Old Testament likewise contains numerous prohibitions against enchanters, confirming Erastus's supposition that all magical arts were forbidden by God. Another common name for them was saga, a wise woman, suggesting a diviner, which Erastus asserted was appropriate since witches often claimed to know more than was naturally possible. Finally, Erastus concluded with what was perhaps the most apt name for them in his demonological schemepraestigiatrix or trickstress-since he asserted that these witches could not do the things they claimed to do but only elicited demonic illusions. ${ }^{59}$

As previously suggested, it was not Erastus's intent to discriminate between types of magical activity in his analysis of the names of witches, but rather to explain how the apparent variations fit into his theory of magic. All names for witches shared overtones of fraud, deception, and trickery, which were hallmarks of diabolical action. His assumption of diabolical agency was the unifying factor in this scheme. Since the devil was the author of all these magical arts, they naturally shared much

59 Repetitio disputationis de lamiis, 5-29. For $\varphi \alpha \varrho \mu \alpha x \varepsilon v \tau \varrho \iota \sigma$, see pp. 6-12; maga, pp. 12-15; lamia, pp. 16-17; strix, pp. 17-18; malefica, p. 18; venefica, p. 18; incantatrix

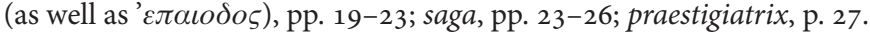


in common: "There is hardly any type of magical operation," claimed Erastus, "which confines itself within its limits, and which does not, to some degree, borrow a part from the others." 60

Although his main motif was to stress the commonality of all magical practitioners, Erastus also contrasted the differences between witches and learned magicians. The first dissimilarity was that the satanic dimension of witchcraft was explicit, whereas, this diabolical aspect was often hidden among learned magicians. Erastus asserted that witches knowingly entered a pact with Satan. In contrast, most learned magicians were not fully cognizant of their reliance on demonic powers. The ironic twist here was that ignorant witches were more fully aware of the diabolical nature of their activity than the more gullible learned magicians. ${ }^{61}$ Second, Erastus suggested that there was a greater chance that learned magicians would repent upon learning their error, because they may have been unaware that they were serving the devil. On the other hand, witches, being fully aware of their homage to Satan, were already obstinate sinners. The third difference concerned how the magical teachings were spread. Magicians took their knowledge of magical arts from books and teachers; theirs was a learned art. On the other hand, Satan himself instructed the witches. The final difference went to their intent in using magical instruments. Erastus recounted that learned magicians frequently employed their art for some trick or joke or in seeking fame. On the other hand, witches almost always used their powers in an attempt to harm someone. Even though magicians might also use their magic for malevolent purposes, evil intentions were more pervasive among witches. The point of Erastus's comparison of witches with learned magicians was to show that witches were at least as bad as these magi, and thus they should not go unpunished. He never forgot the shared characteristics of witches and magicians and suggested that both groups often engaged in activities that were more stereotypically associated with the other. In conclusion, he stressed the commonality of witches and magicians and asserted that one could not draw a hard line between them. ${ }^{62}$

The salient feature of Erastus's conception of witchcraft was that, while he was fundamentally skeptical of the claimed powers of witches, he

${ }^{60}$ Ibid., 24: "Quòd nulla ferè est Magiae Operatricis species, quae intra suos limites se contineat, \& partem aliquam ab aliis non mutuetur."

${ }^{61}$ Ibid., 35 .

${ }^{62}$ Ibid., $35-38$. 
vigorously maintained the reality of the pact with the devil. One might question why, in the wake of the Protestant rejection of much of medieval scholasticism, a skeptically minded Protestant would still cling to this extra-biblical idea of the pact with the devil. Although his retention of the pact might seem inappropriate for a Protestant trained in the humanist tradition, Erastus represents a case study of how the idea of the pact could be reinterpreted in a Protestant manner. In fact, his interpretation of the role of the pact in witchcraft can be read as a projection of a Protestant framework of the necessary relations between humans and superior beings onto the learned witchcraft paradigm.

How did Erastus's conception of the diabolical pact relate to his Swiss Reformed heritage? In no other offshoot of the magisterial Reformation was the necessity for correct performance of ritual so thoroughly debunked and emphasis so narrowly placed on faith as with the Swiss Reformed. Of course, the sacraments of the Lord's Supper and Baptism were maintained, but they were now seen as signs of God's covenant with humans, which required faith for true participation, rather than as rituals whose correct performance required God to grant a benefit. Just as proper performance of ritual was devalued in Reformed religion, so Erastus placed little emphasis on the spells and charms of witchcraft. Yes, witches and magicians might practice such things, but the essence of witchcraft could not be found in them. Here we can observe the ambiguous impact of the Reformed conception of a transcendent God on demonology. Even though Erastus was unwilling to grant demons supernatural powers, he still assumed that humans must call upon a higher force to accomplish something impossible through natural means. Just as Christians must place their faith in God if they desired salvation, witches must fully commit themselves to Satan if they desired to see the fruit of evil. In both cases the capacity of the invoked being to fulfill the request was more important than the correct performance of the spell or ritual. Ironically, Erastus offered an example in which Reformed theological assumptions had taken the "magical" dimension out of both religion and magic. Classical sociology and anthropology have seen the primary difference between religion and magic as existing in how the rituals or spells are employed. A magical act seeks to influence the world by the correct performance of its technique, whereas purely religious actions serve only as acts of prayer and worship to their god; all control over divine intervention is necessarily left to the god's providence. In Max Weber's words, religious petitions to the gods are "supplications," whereas magical formulations for intervention in the natural world are "coer- 
cions." ${ }^{33}$ Bronislaw Malinowski has spoken of magic as "a practical art consisting of acts which are only means to a definite end expected to follow later on." ${ }^{64}$ In Erastus's framework, witchcraft has ceased to be magic in the manner in which it has conventionally been characterized by anthropologists and sociologists, and has become primarily anti-religion. Witchcraft was not per se "black magic," in the sense of magic that seeks to harm others, but rather a satanic cult in which the diabolical pact was the covenant sign of the devil's chosen people.

The pact also had a certain self-evident logic for Erastus. If one accepted that there were individuals who sought to use the devil's powers to work wonders, it was reasonable to assume that these individuals must have some special relationship with the devil. It was common sense that not everyone had access to the devil's powers, as Erastus asked, "For why would not everyone be able [to do such things] if no pact were required?" 65 This assumption too was perhaps an inverse projection of Christianity on witchcraft, with witches now seen as the devil's covenant people. In biblical religion, both in the New and Old Testaments, entry into the community was marked by a symbol reflecting the covenant that had been made between God and humans. The Bible contained no specific reference to the devil making such a covenant with witches, but if the relationship between the devil and the witch functioned like the relationship between God and the believer, it would be reasonable to assume that such a pact existed. Erastus believed that the devil used this threshold to tempt people falsely with greater powers after they had committed themselves to him.

The reinterpreted idea of the pact was at the center of Erastus's theological definition of the crime of witchcraft. The apostasy and spiritual fornication of this act implicated witches in a host of spiritual crimes. Witches were not to be punished because of the marvelous things they accomplished, but because they sought to do the work of the devil. Actual harm, maleficium, had little place in Erastus's understanding of witchcraft. ${ }^{66}$

${ }^{63}$ Max Weber, Economy and Society, trans. Guenther Roth and Claus Wittich, 2 vols. (Berkeley, 1978), 1:422-424. Following Weber, I speak here in terms of ideal types for the purpose of clarity. I do not challenge his caveat that it is perhaps impossible to separate magic and religion completely and, likewise, that most religion retains a measure of magic.

${ }_{64}$ Bronislaw Malinowski, Magic, Science, and Religion (New York, 1955), 88.

${ }^{65}$ Repetitio disputationis de lamiis, 101: "Cur enim non omnes possunt, si pactio nulla requiritur?"

${ }^{66}$ Ibid., 64-65. 
The basic crime of witches was apostasy. Witches were more than simple apostates, however, but heresiarchs, since they spread their cursed heresy of devil worship. ${ }^{67}$ If any heretic merited punishment, these superheretics did, and Erastus did not stop to reflect upon the more fundamental question of whether any heretic should be persecuted.

\section{The Powers of Darkness}

In Erastus's demonology, the devil started out with a marked disadvantage since he could do nothing that was genuinely miraculous. This was because the power to effect a genuine miracle was the same type of power that acted in the creation of the world. A miracle was, in its essence, a "kind of creation." ${ }^{8}$ Indeed, Erastus regarded the miracles that Christ worked in the Gospels as being analogous to God's creation of Eve from Adam's rib. ${ }^{69}$ Only God himself had the power to work such miracles; this ability had not been conceded to the devil. This liability did not mean that the devil could produce nothing at all. Erastus followed the traditional line of thought, such as was expressed in the Malleus Maleficarum, which maintained that the devil could effect "marvels" but not true miracles. ${ }^{70}$ Erastus posited a universe that was not subject to intermediary influences. Unlike the Neo-Platonic chain of being worldview, Erastus's view assumed a transcendent break, characteristic of the Reformed tradition, between the powers of God and the powers of created things. The devil, as a part of the created order, had powers more akin to those of humans than to those of God.

This preliminary liability aside, God had given demonic powers great latitude to work illusions and manipulate nature, all for the purpose of trying the elect. Unlike Weyer, however, Erastus did not outline an encyclopedic treatment of the devil's powers. He also had a tendency, perhaps unconscious, to use diabolus and daemon interchangeably. ${ }^{71}$ The devil/demons had two modes of operating available to them: they could work according to the powers of nature or they could use their special tricks. Like a human being, the devil could produce a change by

\footnotetext{
${ }^{67}$ Ibid., 106-107.

${ }^{68}$ Ibid., 40.

${ }^{69}$ De medicina nova, 1:32-33.

${ }^{70}$ Regarding the similar opinions of Weyer, see De praestigiis daemonum (1583), book 1, ch. 14 .

${ }^{71}$ His favorite term in the first disputation was Cacodaemon.
} 
natural means, although his powers in this realm did not exceed those of humans. Here his ability to manipulate outcomes, as Erastus related, was not superior to those of "a good and diligent farmer." ${ }^{2}$ In contrast with this conservative estimation of demonic power, Erastus also suggested that demons were quite skilled in inflicting disease by natural means. Ostensibly because of the devil's incorporeal nature, he could enter the human body and stir up its spirits and humors. Since the spirits and humors that the devil affected were natural, Erastus did not consider this a supernatural ability. The murky state of physiological knowledge in the sixteenth century made it possible for academic physicians to discuss demonic agency in disease as a genuine scientific possibility. ${ }^{73}$

The special talent of demons consisted of making illusions and tricks. Erastus considered this their chief power and took it quite seriously. Demons could create such tangible illusions that they could actually be seen and touched, though these specters were only representations and not the actual items that they portrayed. Using the metaphor of an artist, Erastus explained, "He who draws a man certainly does not make nothing, since he makes a picture of a man, but he can make nothing of an actual man." ${ }^{74}$ While God had assigned only meager abilities to demonic forces, the devil exploited these in such a way that made it possible for him to engage in sexual relations with a witch. Satan could assume the form of a body, even if it was not true human flesh. He could also employ natural means at his disposal to titillate the humors and spirits of humans. Thus, the devil was able to have a type of intercourse with humans. ${ }^{75}$ While Erastus had a rather philosophically constrained notion of demonic capacity, the devil that he presented was not impotent.

The power of witches, likewise, was limited by the laws of nature and by their dependence on demons. Many witches had an inflated notion of their abilities, imagining themselves able to spread disease, charm

72 Repetitio disputationis de lamiis, 42. "Sed nihilo hic praestantior bono \& diligente agricola ... fuerit."

73 Of course, this limited physiological knowledge not only afforded room for speculation regarding supernatural or diabolical activity; the role of vapors and animal spirits in various diseases (such as melancholia and vertigo) was also hotly debated. For a discussion of the role of humors, vapors, and animal spirits in the case of vertigo, see Andrew Wear, "Explorations in renaissance writings on the practice of medicine," in The Medical Renaissance of the Sixteenth Century, 118-145, especially, 127-139.

${ }^{74}$ Repetitio disputationis de lamiis, 27: "Qui pingit hominem, non facit prorsus nihil, (facit enim pictum hominem) sed veri hominis nihil facit."

75 Ibid., 61. 
lovers, and ruin crops. What they could actually accomplish, however, was severely limited, as Erastus related:

For beyond the desertion of God and the divine cult, and the flight into the camp of the devil, nearly everything [that they claim to accomplish] are fabrications and fictions or positively uncertain and inconstant, slippery and changeable. ${ }^{76}$

Witches could affect terrestrial life by natural means, as could any human. In using natural powers they had some advantage over demons themselves, since some things were difficult for demons to accomplish because of their incorporeal form. However, unlike demons, witches were unable to enter humans and disturb their humors and spirits. ${ }^{77}$ In short, witches had no powers in themselves exceeding other humans. A witch could encourage a demon to action, but the power to act resided in the demon, and not the witch. Nevertheless, Erastus found witches culpable in this regard, since the demon would not have acted without the incitement of the witch. In Erastus's assessment, the fact that demons themselves carried out the action made the witches worse than normal criminals, because they employed such despicable means to accomplish harm. ${ }^{78}$

Erastus's ideas of demonic capacity rested on his interpretation of the two chief instances of sorcery in the Hebrew Scriptures: the stories of Pharaoh's magicians and the famous witch of Endor. In the first of these, Moses and Aaron were sent by God to Pharaoh's court to perform a sign. Aaron cast his staff upon the ground, whereupon it immediately turned into a snake. Pharaoh summoned his own magicians, and likewise they were able to produce snakes "by their enchantments." ${ }^{79}$ In an action suggestive of the superiority of the Hebrew God, the snakes of Aaron consumed the snakes of the Egyptian sorcerers. A critical question for Western demonology has been whether or not the snakes of the Egyptians were real snakes or illusions. In the first volume of De medicina nova, Erastus entertained the various Patristic interpretations of this story. He conceded that Augustine thought that the snakes were real, whereas Tertullian and Clement considered them to be merely phan-

76 Ibid., 33-34: "Nam praeter desertionem Dei, cultusque divini, \& transfugium in castra Diaboli, omnia ferè sunt vel ementita \& ficta, vel certè incerta, inconstantia lubrica mutabilia."

77 Ibid., 42-43.

78 Ibid., 111. See Clark, Thinking with Demons, 520-521.

${ }^{79}$ Exodus 7:11. The biblical quotations in this chapter are from the KJV. All Latin biblical quotations are from the Biblia Sacra Iuxta Vulgatam Versionem, 3 rd ed. (Stuttgart: Deutsche Bibelgesellschaft, 1969). 
tasms. Erastus accepted the latter interpretation, since he would have been forced to concede too much power to the magicians if they had been able to produce actual snakes. Although the text seemed to imply that the snakes were in fact real, Erastus argued that the image of Aaron's snakes devouring the snakes of Pharaoh's magicians indicated that they were merely illusions. ${ }^{80}$ Following this reading of the passage, Erastus drew two important points from the episode. First, magicians could not produce real effects but merely tricks. Second, and more importantly, the passage proved that magicians and witches could produce the appearance of a marvel.

The second major biblical proof text was provided by King Saul's visit with the witch of Endor. In this story, Saul, in a moment of desperation, consulted with a medium to communicate with the recently deceased prophet Samuel. He asked the medium to "divine unto me by thy familiar spirit and bring him up whom I shall name." 81 The woman called upon her familiar spirit to bring up Samuel from the dead. Samuel then appeared before Saul and prophesied his impending doom. One can number at least three agents at work in this act of necromancy: the medium, the familiar spirit, and the late Samuel himself. The sense of demonic agency between the medium and Samuel is confirmed by verse 13 when the medium reports seeing "gods ascending out of the earth." 82 As in the case of the snakes produced by the Egyptian magicians, there is nothing in the narrative to suggest that the medium had not been able to conjure up the real Samuel; the prophetic words that he spoke further suggest that it was God's man himself and not a demonic illusion. Erastus avoided this interpretation of the text, however, and suggested that it was not the real Samuel but rather the devil appearing in the likeness of Samuel ${ }^{83}$ It would create problems both for Erastus's theology and his natural philosophy if the familiar spirit could actually produce the dead Samuel. Such power would mean that the devil or a demon

${ }^{80}$ De medicina nova, 1:39-41.

${ }^{81}$ I Samuel 28:8: "divina mihi in pythone et suscita mihi quem dixero tibi". The Hebrew word for familiar spirit is 'ôwb ['ôb]. The Vulgate translates the Hebrew'ôwb with python, which is in turn a derivative of the Greek $\pi v \vartheta \omega v$. There is no simple word for "medium" in the Hebrew or Latin texts, only the compound suggesting a "woman having a familiar spirit." See Ann Jeffers, Magic and Divination in Ancient Palestine and Syria (Leiden: Brill, 1996), 176. For the general background regarding this text and its import for the Western witchcraft paradigm, see Charles Zika, "Witch of Endor" in Encyclopedia of Witchcraft, 308-310.

${ }^{82}$ ISamuel 28:13b: "et ait mulier ad Saul deos vidi ascendentes de terra."

83 Repetitio disputationis de lamiis, 15. 
could produce an authentic miracle, and Erastus had already philosophically ruled out this possibility. Thus, Erastus insisted on the interpretation that the medium "excited a specter and in a specter of demons, but not Samuel." ${ }^{4}$ Even though Erastus had to bend the literal sense of the text to understand this episode in terms that fit his natural philosophy, he was again able to draw many positive characterizations of witchcraft from it. He surmised that even the witch of Endor realized that she was committing a capital crime in practicing her art, since she had been initially reluctant to do the king's bidding. She made use of a familiar spirit to work her art, and by this "pythonic spirit," she had been able to produce a fake Samuel, reiterating Erastus's belief that convincing illusions could be made with demonic agency. Erastus also noted that the woman was not delirious or possessed by a demon when she conjured the spirit. She also did not inflict any obvious harm by her actions, which supported his contention that the essence of witchcraft did not lie in actual maleficium. Lastly, Erastus asserted that she would not have been able to produce any results if she had not possessed a preexisting relationship with the demon, which Erastus interpreted as being analogous to contemporary witches' pacts with the devil..$^{85}$

Erastus's speculations on sex with the devil and the sexual desires of older women pushed the limits of his inclination to regard the claims of witches skeptically and tended to belie his earlier, more positive statements about the capacities of women. In general, Erastus presented a more positive view of women than Weyer, and yet neither of these men actively undermined the sixteenth century's general assumptions regarding the inferiority of the female sex; both merely had philosophical points to make. ${ }^{86}$ Weyer, seeking to save their lives, frequently cited "weakness and credulity of the female sex" to relieve women of culpability for their alleged crimes. ${ }^{87}$ Alternatively, Erastus desired that women be viewed as competent enough to be held responsible for their misdeeds. ${ }^{88}$ When Erastus sought to make a different point, however, he did not shy away

\footnotetext{
${ }^{84}$ Ibid., 103: "quod umbram excivit, \& in umbra Daemonum, non autem Samuelem: licet opinaretur se Samuelem evocavisse."

${ }^{85}$ Ibid., 103-104.

${ }^{86}$ Regarding the issue of witchcraft and gender in the German context, see Roper, Oedipus and the Devil and Sigrid Brauner, Fearless Wives and Frightened Shrews: The Construction of the Witch in Early Modern Germany (Amherst: University of Massachusetts Press, 1995).

87 Weyer, De praestigiis daemonum (1583), book 3, ch. 7.

${ }^{88}$ Repetitio disputationis de lamiis, 30-31.
} 
from denigrating women. For example, Erastus suggested that the allegation of sex with the devil was made more plausible given the fabled lustfulness of older women. Folk wisdom acknowledged that older women had more inflamed desires than their younger counterparts. ${ }^{89}$ Ironically, it seemed Erastus was more inclined to believe these stories of sex with the devil on account of the heightened lusts of women rather than to credit the devil's tempting power. Not satisfied with this squalor, Erastus interpolated a new justification for the death penalty for witches on the grounds of sexual intercourse with the devil. The command "Whoever lies with a beast shall be put to death" immediately follows the injunction "thou shalt not suffer the witch to live" in the book of Exodus. ${ }^{90}$ Erastus argued that the proximity of these texts was by no means coincidental. Since the devil was not human, like a beast, it followed that individuals who had sex with him should also be put to death. ${ }^{91}$

In comparison to the author of the Malleus Maleficarum, however, Erastus was quite skeptical of the supposed powers of witches and demons. The aforementioned excesses aside, Erastus's writings had none of the misogynistic fervor and were generally devoid of the prurient quality of the Malleus Maleficarum. Erastus was no greater a believer in demonic power than Weyer himself. Likewise, he minimized the actual harm or maleficium that witches were capable of producing and interpreted Scripture in such a way as to minimize demonic power. It is certainly not fair to say, along with Reginald Scot, the great English champion of clemency for witches, that Erastus was "a principall writer in the behalfe of witches omnipotencie."92

Nevertheless, there were two fundamental tensions in Erastus's demonology. On some occasions a strong ambiguity existed between the things that witches attempted to do and what they actually succeeded in accomplishing. Erastus often reeled off lists of things witches claimed to do in

89 Ibid., 113-115.

90 Exodus 22:18-19: The classic line "thou shalt not suffer the witch to live" is actually Exodus 22:17 in the Masoretic text of the Hebrew Scriptures.

${ }^{91}$ Repetitio disputationis de lamiis, 114-115.

92 Reginald Scot, The discouerie of witchcraft (London, 1584; facsimile reprint, New York, 1971), fol. Aiiiiv. Scot's characterization of Erastus has something of a rhetorical aim, since he proceeds to comment that even Erastus recognized that most of a witch's so-called powers were nothing other than illusions and tricks. It is quite noteworthy that, already in 1584 , Scot picked up on this tension between skepticism and credulity in Erastus's work. His countryman Robert Burton had a similar reading of Erastus. See The Anatomy of Melancholy, ed. Thomas C. Faulkner et al. (Oxford: Oxford UP, 1989) pt. 1, section 2, subsection 3 (vol. 1, p. 195). See also Clark, Thinking with Demons, 208. 
such a fashion that the reader might assume that he meant they could actually do these things. At times Erastus himself appeared unsure, as when he argued that witches committed murder, although his earlier statements had implied that they did no harm. ${ }^{93}$ Also, there was apparently a measure of change in Erastus's own attitudes. In Erastus's first treatment of witchcraft, he set out ironclad philosophical categories in which witches and demons had no supernatural powers. Although his fundamental philosophical distinctions remained intact in the Repetitio disputationis de lamiis seu strigibus, when he probed the specific allegations of witches having sex with the devil and the spread of disease by demonic agency, he strained his philosophical distinctions. It puzzles the modern reader that he could characterize the devil's powers as bound by the laws of nature but simultaneously argue that the devil had sex with humans and created illness by natural means. Nevertheless, these contradictions were no less present in the work of Weyer, and in general Erastus presented a less powerful devil than Weyer. ${ }^{94}$

\section{The Punishment of Witches}

As we have seen, Erastus and Weyer inhabited essentially the same worldview regarding what witches could actually accomplish. The controversy between them was focused chiefly on the punishment of witches. Erastus held that witches merited the death penalty according to the scriptural mandate. Since Weyer had endeavored to undercut the biblical foundation of this penalty, Erastus drew upon all possible texts and analogies to support their execution. Thus, Erastus characterized contemporary witchcraft as simply a modern manifestation of forbidden magical arts in order to expand the number of biblical texts that condemned it. Beyond the general prohibition of all magical arts, the Pentateuch included an express commandment to execute witches in Exodus 22:18: "thou shalt not suffer the witch to live." Not only was witchcraft included among the list of forbidden practices meriting the death penalty, God specifically ordered the execution of witches. ${ }^{95}$

Since Erastus did not want to base his case for the death penalty on one verse, he fabricated a list of crimes meriting capital punishment that

\footnotetext{
${ }^{93}$ Repetitio disputationis de lamiis, 52-55.

94 See Midelfort, "Insanity Defense," 248.

${ }^{95}$ Repetitio disputationis de lamiis, 46.
} 
could also be applied to witches. For instance, he argued that witches were guilty of the worst sort of idolatry, since to worship an idol in ignorance was bad enough, but to do homage to the devil knowingly was doubly cursed. Therefore, the Mosaic law requiring the death penalty for idolaters also applied to witches, since they were the worst possible kind of idolater. ${ }^{96} \mathrm{He}$ also argued that they deserved death because they actively seduced others into their error. ${ }^{97}$ They were also guilty of murder and of knowingly practicing proscribed arts. Finally, as discussed above, Erastus proposed his most fantastic accusation in alleging that they merited the death penalty because they engaged in bestial sex. ${ }^{98}$

Weyer had attacked the command of Exodus 22:18 by arguing that the text did not apply to witches or sorcerers at all, but rather that the law was meant to condemn poisoners. He based this assertion on a clever philological analysis of the Old Testament, both of the Hebrew text and Greek and Latin translations, in which he called upon the expertise of Jewish Hebrew scholars. ${ }^{99}$ The chief thrust of his argument was to accept the Septuagint's translation of the Hebrew Mekashshephah with

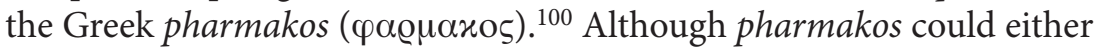
mean a poisoner or a sorcerer, Weyer stressed the word's etymological root and asserted that it must denote a poisoner in Exodus 22:18. In Weyer's understanding, the passage should read: "thou shalt not suffer the poisoner to live." Such an interpretation undercut the only explicit Old Testament law used to mandate capital punishment for witches.

Erastus rejected the notion that the command of Exodus 22:18 was meant to condemn poisoners rather than those practicing magical arts.

${ }^{96}$ Ibid., 50-51.

97 Ibid., 51-52.

98 Ibid., 60-61.

99 Weyer, De praestigiis daemonum (1583), book 2, ch. 1, cols. 135-143; Mora, Witches, Devils and Doctors, 93-98.

100 The Hebrew word is mekashshephah [měkaššēpâ], whose root idea has the connotation of whispering a spell (i.e., enchanting). The modern scholarly consensus is that the word in Hebrew Scriptures in fact has the connotation of enchantress or sorceress rather than poisoner. Since Exodus 22:17/18 does not include a description of the crimes of the mekashshephah, however, it impossible to establish clear definition of the crime of "witchcraft" using this passage. De praestigiis daemonum (1583), book 5, col. 26; Mora, Witches, Devils and Doctors, 542-547. See Graham Harvey, "The Suffering of Witches and Children: Uses of the Witchcraft Passages in the Bible," in Words Remembered, Texts Renewed, ed. Jon Davies et al., Journal for the Study of the Old Testament, Supplement Series 195 (1995): 113-134; Jeffers, Magic and Divination in Ancient Palestine and Syria, 68; The Hebrew and Aramaic Lexicon of the Old Testament, ed. Ludwig Koehler et al. (Leiden: Brill, 1994-2000). 
To refute Weyer's interpretation, he was forced to engage in a similar philological study. His effort focused on the meaning of the Greek word pharmakos, since it, rather than the Hebrew mekashshephah, was the key to Weyer's argument. He established a range of meanings and showed that pharmakos had a long heritage of denoting enchanter or sorcerer and not simply poisoner, a position he established by references to authors such as Plato and Galen. ${ }^{101}$ With a humanist's acumen, he put forward sound criteria for establishing a word's meaning by first considering the range of meanings possible for the word, but ultimately allowing the context to offer the final determination. In line with this methodology, he suggested that Old Testament meanings were more critical in interpreting the Exodus passage than their extra-biblical usage. ${ }^{102}$ In this context he made the point that the translators of the Septuagint had also used a word from the pharmakon family to describe Pharaoh's magicians in Exodus 7. Thus, Erastus was able to produce a clear case where pharmakos had a connotation of incantation. Alternatively, he argued that Weyer's proposed interpretation was untenable, since he could not produce one biblical example where pharmakos meant poisoner. Erastus concluded, on the basis of the range of meaning of pharmakos in the Bible, that the traditional understanding of the Exodus 22:18 command to kill the witch remained valid.

Another of Weyer's strategies was to assert that modern witches were unknown in biblical times and, therefore, that the Mosaic law could not be interpreted as pertaining to them since they did not exist at the time of Moses. This challenge was broader than simply exempting them from the direct mandate of Exodus 22:18; if fully accepted, it would have meant that sixteenth-century witches were not liable for the more broadly proscribed arts of divination and incantation. Weyer displayed a measure of that famous Renaissance historical awareness in asserting that the crimes of which modern witches were accused were vastly different from the activities of the Old Testament's enchanters and diviners. Erastus countered this argument by generalizing the conception of a magician and conflating it with the much more common Old Testament notion of an enchanter. Although he had enough literary acumen to perceive the differences among the various groups of magical practitioners, he was theologically constrained to argue that they all were members of the same diabolical family. In Erastus's theory, the specific form of satanic activ-

101 Repetitio disputationis de lamiis, 90-93.

102 Ibid., 88. 
ity might change from time to time, but the devil remained the author of all such arts. This ploy saved Erastus from committing the historical anachronism of asserting that modern witches were one and the same as biblical enchantresses. He maintained that the law of God was flexible enough to treat the general concept of magic and did not limit its relevance by addressing only its ephemeral forms. ${ }^{103} \mathrm{He}$ admitted that it was possible that there would be new types of magicians; nevertheless, anyone who sought diabolical assistance was by definition a magician. Erastus strengthened his argument for the antiquity of witchcraft by citing numerous texts by classical authors that offered examples of various enchantresses and sorcerers. He was thus able to employ a humanist's knowledge of antiquity, much as Gianfrancesco Pico della Mirandola had done before him, to buttress belief in witchcraft. ${ }^{104}$ The dispute between Erastus and Weyer thus yields an example of the ambiguous impact of humanism on the witchcraft debate. Both men displayed a measure of humanist incredulity that would have been uncommon for earlier scholastics. ${ }^{105}$ In the case of Weyer, historical criticism was used for the benefit of those accused of witchcraft; with Erastus, knowledge of classical texts was used against the witches. In this example, humanism itself was a neutral factor in the debate on the punishment of witches, depending on how the particular humanist desired to wield the weapon. The impact of humanism on the witchcraft debate was ultimately analogous to its impact on the question of astrology, where we likewise find humanists on both sides of the issue. The combined examples suggest that the humanist method had only a marginal impact as an agent of "disenchantment."

Weyer had also invented a forerunner of the modern insanity defense to win acquittal for those accused of witchcraft. Weyer argued that old women who were incompetent by excesses of melancholia-literally, black bile-merely imagined the silly things they confessed. Thus, even

\footnotetext{
${ }^{103}$ Ibid., 81-83.

104 Peter Burke, "Witchcraft and Magic in Renaissance Italy: Gianfrancesco Pico and his Strix," in The Damned Art: Essays in the Literature of Witchcraft (London: Routledge \& Kegan Paul, 1977), 32-48.

105 This is not to suggest that most humanists were skeptics in the mode of David Hume. I follow Kristeller here when he notes that "the humanists did not place much credence in miracles and avoided theological speculations ...." Paul Oskar Kristeller, Renaissance Thought and the Arts (Princeton, Princeton UP, 1990), 10. Weyer certainly surpassed Erastus as a debunker of alleged stories of witchcraft and miracles. See especially his investigation of the case of Barbara Kremers, a young woman who supposedly lived without eating. Mora, Witches, Devils and Doctors, lxvii-lxix.
} 
if they thought they had entered a diabolical pact, they should be treated mercifully by reason of their impaired condition. Erastus countered this argument by first asserting that witchcraft was not a crime limited to old women, since young people and even men became entangled in it. He did not dispute the idea that many practitioners of witchcraft were feeble-minded individuals; however, he rejected the fallacy that all who fall under the devil's spell were mentally incompetent. While it might have seemed to befit Christian charity to offer clemency to these women, Erastus argued that such mercy was restricted by the word of God. Thus to forgive them would be damnable rather than praiseworthy. ${ }^{106} \mathrm{He}$ also attacked the idea that the alleged witches had merely dreamt the things they confessed. He maintained that they were fully cognizant of their decision to ally themselves with the devil; if not, why did they try so hard to cover up their actions? 107

Weyer's most penetrating critique of the supposed crime of witchcraft had been to attack the legal foundations of the idea of the pact. Weyer undermined the validity of the pact from the perspective of Roman contract theory. Roman law rejected both contracts in which only one party would profit (leonine contracts) and contracts in which one party was not fully aware of the stipulations of the contract. Weyer argued that a witch's pact with the devil violated both of these conditions and was therefore an invalid contract, since only the devil could gain while the witch lost. Furthermore, the devil would not fulfill the extravagant promises he made to the witch to entice her to enter the pact. There were multiple grounds in Roman law to consider the diabolical pact a fraudulent and unenforceable contract. ${ }^{108}$

Ironically, Erastus did not engage Weyer's repudiation of the pact on legal grounds. Despite Erastus's general competence, he admitted that he was not familiar with Roman law and made a plea in the introduction of the Repetitio disputationis de lamiis seu strigibus for someone more proficient than himself to challenge Weyer on this issue. ${ }^{109}$ Erastus did not think of a witch's contract with the devil in the Roman legal sense as a binding agreement between two good faith individuals; rather, he employed the analogy of the ancient Israelites' covenant with Jehovah.

\footnotetext{
106 Repetitio disputationis de lamiis, 109.

107 Ibid., 30-31.

108 Midelfort, "Insanity Defense," 243-245.

109 Repetitio disputationis de lamiis, fol. $):\left(4^{\mathrm{r}}\right.$.
} 
Erastus's conception of the pact was a theologically rather than a legally defined idea.

The fundamental philosophical difference between Erastus and Weyer was that Erastus believed that the pact was possible, whereas Weyer thought that it was as fictitious and imaginary as the other activities witches confessed. Weyer summarized their disagreement as follows:

These women claim that they fly through the air, are transformed into beasts, excite storms and cause disease by their imprecations.... And yet I have shown, and you admit along with me, that all these things are vain and contrived and tinged with diabolical fiction. And if they are vain, why should the other things that they confess be true.... I know what it is here that deceives the philosopher. He sees that all of the former claims are impossible, and therefore he agrees with me and pronounces them false and meaningless; but he thinks that the latter things have been done because they can be done, and because the Strigae themselves confess to doing them. ${ }^{110}$

The title "the philosopher" would appear to be a direct reference to Erastus. With this deft maneuver, Weyer could both compliment Erastus by placing him in the company of Aristotle and chide him on account of his lack of direct experience in sorting out such outrageous claims. Nevertheless, Weyer correctly perceived that he had not been able to prove to Erastus's satisfaction that the pact was actually impossible. Whereas Erastus might not believe witches' outlandish tales, he still believed that it was possible for witches to abandon God and enter the society of the devil. Their confessions of entering a pact with the devil were believable, since they actually could do this. Erastus believed the Scriptures attested to this possibility and asserted that the "experience of all the centuries proves the same." 111 To this belief Weyer could only retort, "Does he not see the devil's fallacy - that he wishes us to conclude the impossible from the possible?"112 Weyer's argument, however, constructed on an insubstantial logical ploy, could not overturn Erastus's claimed evidence from Scripture and experience. Ironically, Weyer himself had to strengthen his case by emphasizing the cunning of demonic agency. ${ }^{113}$

\footnotetext{
110 De praestigiis daemonum (1583), book 6, ch. 24, cols. 751-752. Quoted from Mora, Witches, Devils and Doctors, 549-550.

111 Repetitio disputationis de lamiis, 100.

112 De praestigiis daemonum (1583), book 6, ch. 24, col. 752. Quoted from Mora, Witches, Devils and Doctors, 550.

113 Such statements from Weyer reinforce Midelfort's insight that Weyer sought to undermine the supposed crime of witchcraft "by affirming that he [the devil] was more powerful than was usually thought." Midelfort, "Insanity Defense," 237.
} 


\section{Conclusion}

Erastus's critique revealed the weakness of Weyer's arguments for clemency toward those accused of witchcraft as addressed to a learned, sixteenth-century audience. It was because Weyer argued so boldly that the crime of witchcraft was impossible that intellectuals like Erastus found his arguments so implausible. The inadequacy of Weyer's defense of witches was not unlike Galileo's failed argument that the existence of tides proved the earth's movement. Of course, Galileo's theory of diurnal motion was correct, but the specific argument he chose to prove his point missed the mark. Likewise, while Weyer correctly grasped that the entire witch-trial process was a tremendous miscarriage of justice, many of his supporting arguments, while perhaps ingenious, were more than an intellectually honest sixteenth-century scholar could swallow.

Erastus's response to Weyer must be viewed as a humanistically constructed refutation by a man who possessed nearly identical assumptions regarding the operation of the natural world and the devil's role in it. Erastus was neither an avid witch-hunter nor a convinced believer in diabolical power. He was not personally involved in persecuting witches, and his book was neither a program nor a manual for persecuting witches. ${ }^{114}$ His writings did not encourage a wholesale persecution in the Palatinate, which remained almost completely untouched by the later waves of witch-hunting. ${ }^{115}$ Erastus also made statements to the effect that there had often been abuses in witchcraft trials and that the innocent may have wrongly suffered. ${ }^{116}$ Ultimately what distinguished Erastus from Weyer was his limited first-hand familiarity with witch trials, not his belief in the devil. In an academic setting in a principality that had not

114 Thus I dissent from Anneliese Staff's assertion that "Erastus setzt sich für eine intensive Verfolgung ein." Anneliese Staff, "Von Hexen/ Zauberer/ Unholden/ Schwartkünstler/ und Teufeln ... Bibliographie zu den Beständen der Hexenliteratur der Herzog August Bibliothek Wolfenbüttel," in Vom Unfug des Hexen-Processes, 374. Schmidt concurs: "Da Erast kein Verfolgungshandbuch geschreiben hat, sondern prozessferne Thesen im akademischen Rahmen diskutierte, scheint er keine directe Wirkungen auf konkrete Hexenverfolgung gehabt zu haben, sondern nur einem Widerhall in der gelehrten Diskussion." Schimdt, Glaube und Skepsis, 168.

115 The Palatinate had been an early leader in the reception of the learned witchcraft paradigm in Germany. An acute outbreak of disease in Heidelberg had been blamed on witchcraft in 1446-1447, which led to the execution of eight alleged witches. However, the Palatinate saw no major witchcraft trials in the sixteenth century and, after its positive reception of Weyer's views, became one of the most persecution resistant states in the Holy Roman Empire. Schimdt, Glaube und Skepsis, passim.

116 De medicina nova, 1:214. 
suffered an outbreak of witch trials for approximately seventy years, Erastus remained convinced of the theological possibility of witchcraft. Likewise, he believed in the authenticity of the witches' confessions for the same reasons that convinced the majority of sixteenth-century intellectuals; after all, some men and women had confessed to the crime voluntarily. ${ }^{117}$ Since Erastus's skepticism regarding demonic powers was quite strong for a sixteenth-century intellectual, my study supports the conclusions of H.C. Erik Midelfort and Stuart Clark that the eventual lack of faith in the judicial system that extracted the confessions and recriminating accusations was much more important in bringing about the end of witch-hunting than an absence of faith in devil or witchcraft. ${ }^{118}$ Unfortunately, Erastus knew far too little about actual witch trials to anticipate this future crisis of faith in the machinery of witchcraft proceedings.

The fundamental message of Erastus was to suggest that, even though there were abuses in witch trials and that witches really could do no harm, Weyer had gone too far when he said that they were all deranged women and that the death penalty should not apply to them. Unfortunately, Erastus's writings probably spread a less subtle message: witches must be killed. That his arguments were later picked up by demonologists across the confessional divide and even reprinted as an accompanying text to Nicolas Jacquier's Flagellum haereticorum fascinariorum reveals how useful the witch-hunters found Erastus's critique of Weyer. ${ }^{119}$ Although Erastus may have scored some technically correct philological and theological points in his demonological writings, he failed to grasp the human tragedy of the witch-hunt. In the case of witchcraft, which Erastus appears to have addressed solely as an academic question, his lack of experience with the human dimension of the problem allowed him to arrive at an orthodox interpretation of Scripture, if a much less humane conclusion. It was a conclusion with consequences, and Erastus must take his place as one of the figures who defended an intellectual paradigm that allowed approximately fifty thousand women and men to lose their lives

\footnotetext{
117 Repetitio disputationis de lamiis, 98-116, passim, especially 107.

118 H.C. Erik Midelfort, Witch-hunting in Southwestern Germany 1562-1684 (Stanford: Stanford UP, 1970), 162-163; Stuart Clark, "Glaube und Skepsis in der deutschen Hexenliteratur von Johann Weyer bis Friedrich von Spee," in Vom Unfug des HexenProcesses, 15-33. On the question of the limits of Weyer's appeal, see Clark, Thinking with Demons, 198-209 and Christopher Baxter, "Johann Weyer's De praestigiis daemonum: Unsystematic Psychopathology," in The Damned Art, 53-75.

119 Niklaus Paulus, Hexen und Hexenprozeß vornemlich im 16. Jahrhundert (Freiburg im Breisgau, 1910), 69.
} 
in the early modern period. ${ }^{120}$ Given the magnitude of the tragedy, it is fitting to hear Weyer's prophetic word regarding the irresponsibility of his detractors' arguments:

Unwittingly these writers provide drawn sword and kindling for the savage executioners, who lack judgment, discretion and any trace of pity. ${ }^{121}$

Erastus's harsh position on witches remains a dual enigma when viewed from the perspective of the rest of his career. Whereas Erastus had adopted a more liberal position in the controversy over church discipline, which had led some of his colleagues to suggest that his ideas would lead to atheism, Erastus supported the conventional wisdom on the question of punishment of witches. In the church discipline controversy, Erastus's experience with arbitrary clerical power made a critical impact on Erastus's reading of scripture. In short, being mindful of the history of ecclesiastical tyranny, he was inclined to interpret the biblical proof texts for church discipline rather differently from his Calvinist brethren. Not unlike Weyer's attack on witchcraft, in the case of excommunication Erastus was able to gaze across centuries of theological tradition and boldly proclaim that the emperor was wearing no clothes. But Erastus lacked the personal experience with witch trials needed to humanize his demonology, and his witches were more theoretical heretics than real ones. The other paradox regards Erastus's own disenchanted outlook, which he appeared to transgress by granting the devil certain natural powers to harm humans. On limited occasions, Erastus sounded more like the individuals he had attacked so vigorously in his anti-Paracelsian disputations; for example, Renaissance thinkers who had supported various types of magical practices precisely because they were natural or Melanchthon, who wanted to understand the natural influences of the stars on earthly existence. If Erastus allowed that the devil could manipulate such natural powers, one might ask what prevented humans from manipulating these same powers. There is no simple resolution to this contradiction in Erastus's thought. It was real, and it was perceived by Erastus's contemporary Reginald Scot, who proclaimed: "Erastus disagreeth herein with himselfe and his freends" in that Erastus had oth-

120 The estimate of fifty thousand executions between $1400-1800$ is from Wolfgang Behringer, Witches and Witch-Hunts: A Global History (Cambridge: Polity, 2004), 156157. For a regional breakdown of the estimated numbers of trials and executions, see Levack, Witch-hunt, 20-24.

${ }^{121}$ De praestigiis daemonum (1583), book 2, ch. 1, col. 143. Quoted from Mora, Witches, Devils and Doctors, 98. 
erwise maintained that all of the witches' wiles were simple tricks and illusions. ${ }^{122}$ Erastus's powerful Reformed animus against magic and idolatry apparently won out over his skepticism. It was an extension of his tendency to deny the legitimacy of any claimed natural magic and point to its necessary demonic quality. ${ }^{123}$ Particularly in the Repetitio disputationis de lamiis seu strigibus, his tendency to emphasize demonic agency took precedence over more empirical arguments. Because of their diabolical perversion of the Christian cultus, Erastus's textbook witch was a heresiarch and super-idolater who deserved death.

Finally, Erastus's demonological treatises must be placed in the context of his history of self-fashioning. In 1570 Erastus's allies had come under deep suspicion of heretical activities. By 1577 Erastus had survived a more serious inquest into his orthodoxy, only to be made a confessional outsider once again with the re-conversion of the Palatinate to Lutheranism. Not unlike his anti-Paracelsian works, his disputations on witchcraft assisted Erastus's attempt to recover a reputation in the cultural and religious mainstream.

Figure 2. Passages from Erastus and Weyer are set in parallel columns for comparison. The identical or nearly identical words and phrases have been placed in italics. The correspondence between the passages is even greater when one takes into account the occasions when Weyer has translated Erastus's Greek text into Latin. The magnitude of direct borrowings from Erastus's text, which Weyer quoted in order to refute him, leave no doubt as to the identity of Weyer's "adversary."

Erastus, Repetitio disputationis de lamiis, Weyer, De praestigiis daemonum, 1583 [1578]

pp. $90-92$

col. 742, line 45-col. 744, line 26

Dioscorides cap. de Rhamno

ait, Fertur ramos eius, si pro forib. aut fenestris ponatur ( $\alpha \pi о \varkappa \varrho \varepsilon v \varepsilon \iota v \tau \alpha \varsigma \tau \omega \nu \Phi \alpha \varrho \mu \alpha \varkappa \omega \nu$

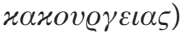
malefica pharmacorum seu incantamentorum pellere....

Dioscorides velit nolit, cap. de Zhamno obtruditur:

Fertur, ramos eius, si pro foribus aut fenestris ponatur,

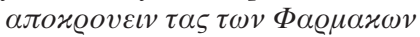
xaxov@ $\gamma \varepsilon \iota \alpha$. quod adversarius vertit, Malefica pharmacorum seu incantamentorum pellere...

122 Scot, Discoverie of Witchcraft, fol. Aiiiiv.

123 See Walker, Spiritual and Demonic Magic from Ficino to Campanella, 156-166; Clark, Thinking with Demons, 244. 
Galenus rarò sic usus est, fateor Causa est in medio posita. Docere enim artem Medicam, non

Malificia \& incantationes voluit: quòd initio

lib. 6. de Simpl. pharm. Facult. testatur....

Sic cum

Secundo libro de Compositione

pharmacorum

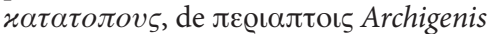

loquitur, de eis se nihil dicturum ait, quia

nullam rationem Medicam

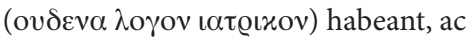
sola experientia iudicentur. Vocasse

nihilominus talia

unà cum aliis, $\Phi \alpha \varrho \mu \alpha x \alpha$, licet inania \& inefficacia iudicaret, ex dictis constat. Sed \& decimo libro citati prius operis, haec habet.

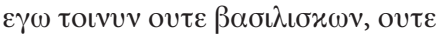

$\varepsilon \lambda \varepsilon \varphi \alpha \nu \tau \omega v$,

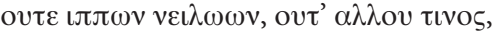

ov $\mu \eta \pi \varepsilon เ \varrho \alpha v \alpha v \tau \circ \varsigma \varepsilon \chi \omega, \mu \nu \eta v o \mu \varepsilon[] \sigma \omega$.

$\tau \omega v \delta \varepsilon \varkappa \alpha \lambda \circ v \mu \varepsilon v \omega v$ $\varphi 1 \lambda \tau \varrho \omega v$,

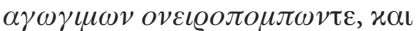

$\mu \iota \sigma \eta \vartheta \varrho \omega \nu$,

...

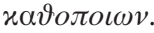

Hippocr. Etiam libro de morbo sacro

$\pi \varepsilon \varphi \alpha \varrho \mu \alpha \gamma \mu \varepsilon v o v \varsigma v \pi \alpha \nu \vartheta \varrho \omega \pi \omega \nu$ vocare videtur incantatos laesos, cum ibi de curationibus Magicis agat.
Nec contra nos facit, quod ex

sexto lib. Galeni de Simpl. pharmac. facult. adducitur de voce Pharmaco: quemadmodum nec omnino liquet ex Galeni verbis, quod non candidè

objicitur, ubi lib. 2

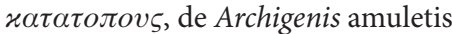
loquitur, ad capitis dolorem ea se relicturum, ut nullam medicam rationem habentia, ait: ...

libro 10. de Simplic. adversus me torqueatur, ubi

se basiliscorum aut elephantorum

\& equorum Nileorum, neq[ue] alterius cuisquam, cuius ipse periculum non fecerit, mentionem se facere nolle asserit: nec etiam velle meminisse poculorum amatorum,

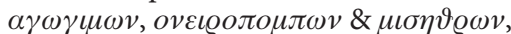
etiamsi

abundè illa expertus esset, sicuti nec lethalium medicamentorum, aut, ut ipsi vocant, $\pi \alpha \vartheta \circ \pi \circ \iota \nu$.

Quod item Hippocrates libro de Morbo sacro in auxilium accersatur, sit potius calumniae exaggerandae causa, quàm veritatis defendendae velut $\&$ aliis locis. siquidem $\varphi \alpha \varrho \mu \alpha \gamma \mu \varepsilon v o v \varsigma$ vл $\alpha \nu \vartheta \varrho \omega \pi \omega v$ vocare videtur incantatos laesos, cum ibi de curationibus magicis agat: ita scribit adversarius. 